Ambiente \& Água - An Interdisciplinary Journal of Applied Science
ISSN 1980-993X - doi:10.4136/1980-993X
www.ambi-agua.net
E-mail: ambi.agua@gmail.com

\title{
Simulation of nitrate and potassium concentrations in soil solution using parametric models and Hydrus-2D
}

\author{
ARTICLES doi:10.4136/ambi-agua.2606
}

Received: 25 Jun. 2020; Accepted: 15 Dec. 2020

\author{
Beatriz Santos Conceição ${ }^{1}$; ; Eugênio Ferreira Coelho ${ }^{2}$; \\ João José da Silva Junior ${ }^{3 *}$; ; José Antonio do Vale Sant'Ana1 ${ }^{1}$; \\ Mauro Aparecido Martinez ${ }^{4}$ (D)
}

\footnotetext{
${ }^{1}$ Departamento de Agronomia. Instituto Federal de Educação, Ciência e Tecnologia de Mato Grosso (IFMT), Avenida Vilmar Fernandes, $n^{\circ}$ 300, CEP: 78652-000, Confresa, MT, Brazil.

E-mail: beatriz.conceicao@cfs.ifmt.edu.br, jose.santana@cfs.ifmt.edu.br

${ }^{2}$ Embrapa Mandioca e Fruticultura (EMBRAPA), Rua Embrapa, s/n, CEP: 44380-000, Cruz das Almas, BA, Brazil. E-mail: eugenio.coelho@embrapa.br

${ }^{3}$ Faculdade de Agronomia e Medicina Veterinária. Universidade de Brasília (UnB), Campos Universitário Darcy Ribeiro, Asa Norte, CEP: 70910-900, Brasília, DF, Brazil.

${ }^{4}$ Departamento de Ciência do Solo. Universidade Federal de Viçosa (UFV), Avenida Peter Henry Rolfs, s/n, CEP: 36570-000, Viçosa, MG, Brazil. E-mail: mmauro@ufv.br

*Corresponding author. E-mail: jjsjunior@unb.br
}

\begin{abstract}
This study estimated the nitrate and potassium concentration in the soil solution of drainage lysimeter using the mathematical models developed by Vogeler et al. (1996) and MuñozCarpena et al. (2005) and the computational model Hydrus-2D, while comparing the simulated and observed data using statistical parameters. The cultivar used for the study was 'Prata Gorutuba'. The experimental plots were six lysimeters of drainage. Fertigation was performed weekly. The mathematical models developed by Vogeler et al. (1996) and Muñoz-Carpena et al. (2005) were used to determine the specific concentration of a given ion (Ci). The Hydrus software was used to simulate the dynamics of nutrients. The concentrations of nitrate and potassium in the soil solution were estimated by the model of Vogeler et al. (1996), adapted to the linear type CEw-Ci ratio and simulated by the Hydrus model, resulting in an acceptable characterization of the distribution of these nutrients.
\end{abstract}

Keywords: banana, fertigation, lysimeter, modeling, nutrients.

\section{Simulações das concentrações de nitrato e potássio na solução do solo utilizando modelos paramétricos e o Hydrus-2D}

\section{RESUMO}

O objetivo deste trabalho foi estimar a concentração de nitrato e potássio na solução do solo, em lisímetro de drenagem com o uso dos modelos matemáticos desenvolvidos por Vogeler et al. (1996) e Muñoz-Carpena et al. (2005) e do modelo computacional Hydrus-2D e comparar os dados simulados e observados usando parâmetros estatísticos. A cultivar utilizada para o estudo foi a 'Prata Gorutuba'. As parcelas experimentais foram seis lisímetros de drenagem. A fertirrigação foi realizada semanalmente. Os modelos matemáticos desenvolvidos por Vogeler et al. (1996) e Muñoz-Carpena et al. (2005), foram utilizados para determinar a concentração 
específica de um determinado íon (Ci). O software Hydrus foi utilizado para simular a dinâmica de nutrientes. As concentrações de nitrato e potássio na solução do solo, estimados por meio do modelo de Vogeler et al. (1996) adaptado para a relação CEw-Ci do tipo linear e simulado pelo modelo Hydrus apresentou uma caracterização aceitável da distribuição desses nutrientes.

Palavras-chave: bananeira, fertirrigação, lisimetro, modelagem, nutrientes.

\section{INTRODUCTION}

Water is one of the main factors limiting crop development, with special importance in certain phenological phases in which its deficiency can more or less significantly compromise productivity (Vanhove et al., 2012; Ravi et al., 2013; Muthusamy et al., 2014; Kissel et al., 2015).

A few years ago, a change in the traditional form of fertilization of irrigated crops occurred with the application of fertilizer via irrigation water. According to Langoni et al. (2019), in order for the irrigated crop to be viable it is necessary to adopt management that contributes to the increase of productivity and profit, in which fertigation is a technology that offers easy benefits in the parceling of fertilizer, providing nutrients according to the phenological stages of the crop more responsive to absorption.

In fertigated areas, the monitoring of the spatial and temporal variation of the water content $(\theta)$, the electrical conductivity of the soil (CEs), the electrical conductivity of the soil solution (CEss) and the ionic concentration (Ci), makes it possible to estimate the loss of water to deep percolation and evapotranspiration of the crop, in addition to determining the regions of nutrient extraction by the plants and the possible loss of nutrients to leaching (Santana et al., 2007).

For monitoring the distribution of water and ionic solutes in the soil, time domain reflectometry (TDR) has been used successfully in several studies (Vogeler et al., 1996; Persson and Uvo, 2003; Santos et al., 2010), due to the relationship between the apparent electrical conductivity of the soil and the electrical conductivity of the soil solution (CEw), and between $\mathrm{CEw}$ and the ionic concentration $(\mathrm{Ci})$.

Considering the computational advances in recent years, a viable alternative is the use of analytical and numerical models that predict the processes of water and solute transfer between the soil surface and the groundwater table. Among the computational models available in the literature, the Hydrus model has been distinguished by the accuracy of the results (Nimmer et al., 2009; Silva et al., 2015; Kanzari et al., 2012; Pinho and Miranda 2014; Ramos et al., 2013), and also by its graphical interface that allows for a good interaction with different types of users. However, the approach for calibration and validation of the model can vary greatly, depending on the complexity of the experiment.

The main advantage of using models is that it saves time and capital, since field experiments and laboratories are usually laborious, expensive and time-consuming (Martinez et al., 2010). Nevertheless, it is worth noting that field measurements are indispensable, since mathematical models require local calibration and validation (Rivera et al., 2008).

Techniques for solving equations and the available computational resources can predict the contamination risks and impacts that the chemical components might cause to the soilwater-plant system (Garcia et al., 2012).

The use of multidimensional modeling is indispensable for developing fertigation practices, and optimized to achieve optimal nutritional efficiency for plants. Thus, in recent decades several analytical and numerical models have emerged to predict the processes of water and solute transfer between the soil surface and groundwater (Pinho and Miranda, 2014).

According to Kunz et al. (2014), the use of simulation models describing the flux of water in the soil, such as Hydrus 2D/3D, can be useful to explain the behavior of water in porous media, provided they are properly calibrated and validated from field experiments. 
Elmi et al. (2012) investigated the vertical distribution of water in a soil column using Hydrus and observed that the estimated soil moisture values did not correspond to the measured values. According to the authors, the result may be associated with heterogeneity in soil profile, which was not considered in the discretization of the model. This result differs from that of Silva et al. (2015) who, seeking to model soil moisture dynamics through the Hydrus Model, reported that the results ensure the possibility of using the model to estimate soil moisture at a daily scale for the type of soil and coverage conditions investigated.

Kanzari et al. (2012) also characterized water movement by using TDR probes installed up to $4 \mathrm{~m}$ deep, using Hydrus to model water movement in a semi-arid region of Tunisia, and found that the simulated data showed the same trend as the measured data. Pinho and Miranda (2014), evaluating the application of the Hydrus model as well as its performance in potassium and water displacement simulations (in Red-Yellow Latossoil and Red Nitossoil), concluded that the Hydrus model was efficient in potassium and water displacement simulations in the two soil materials studied.

Ramos et al. (2013) used the Hydrus model to simulate the dynamics of water and nitrogen forms in a soil cultivated with saccharine sorghum, bearing different salt contents and fertigation levels, and reported that simulations with Hydrus were useful to understanding the best strategies to increase nutrient uptake by plants and reduce losses to leaching.

Thus, the present work aimed to estimate the concentration of nitrate and potassium in the soil solution in drainage lysimeter using the mathematical models developed by Vogeler et al. (1996) and Muñoz-Carpena et al. (2005) and the computational model Hydrus-2D, while comparing the simulated and observed data using statistical parameters.

\section{MATERIAL AND METHODS}

The experiment was conducted at the National Center of Cassava and Fruticulture Research (CNPMF), belonging to the Brazilian Agricultural Research Corporation (EMBRAPA), located in the municipality of Cruz das Almas - BA $\left(12^{\circ} 40^{\prime} 12^{\prime \prime} \mathrm{S} ; 3^{\circ} 06^{\prime} 07^{\prime \prime} \mathrm{W}\right.$; $220 \mathrm{~m}$ altitude) The climate is Aw and Am, classified in the Koppen classification as tropical hot and humid. The cultivar used for the study was the 'Prata Gorutuba' (Musa AAB 'Prata Anã' clone: Gorutuba).

The treatments used in this experiment were obtained by the combination of two soils of distinct texture (sandy clay and sandy frank sand) and three concentrations (3.0, 6.0 and $9.0 \mathrm{~g}$ $\mathrm{L}^{-1}$ ) for application of potassium nitrate in the irrigation water for the banana tree 'Prata Gorutuba', totaling six treatments (sandy clay soil with $3 \mathrm{~g} \mathrm{~L}^{-1}(\mathrm{~T} 1)$, sandy clay soil with $6.0 \mathrm{~g}$ $\mathrm{L}^{-1}$ (T2), sandy clay soil with $9.0 \mathrm{~g} \mathrm{~L}^{-1}$ (T3), free sand soil with $3.0 \mathrm{~g} \mathrm{~L}^{-1}$ (T4), free sand soil with $6.0 \mathrm{~g} \mathrm{~L}^{-1}$ (T5), and free sand soil with $9.0 \mathrm{~g} \mathrm{~L}^{-1}$ (T6), which were distributed in an experimental design entirely randomized with four repetitions. The repetitions were composed of the four radial planes, containing TDR probes and solution extractors (installed at 0.20, 0.40, 0.60 and $0.80 \mathrm{~m}$ distance and depth $(\mathrm{r}, \mathrm{z})$ on each lysimeter.

The lysimeters have a capacity of $5.0 \mathrm{~m}^{3}$, measuring $2.0 \mathrm{~m}$ wide, $2.5 \mathrm{~m}$ long and $1.0 \mathrm{~m}$ deep. To create a free drainage system, the last $0.2 \mathrm{~m}$ of the profile was divided in two layers of $0.1 \mathrm{~m}$, the lower one composed of a drainage system with perforated PVC tubes at $0.05 \mathrm{~m}$ and zero gravel, and the upper one with washed sand. Samples of the soils were taken at depths of $0.0-0.4 \mathrm{~m}$ before the plantation of the banana tree and sent to the soil and nutrition laboratory of Embrapa - CNPMF for chemical analysis (Table 1).

Table 2 shows the physical characteristics of the two types of soil used in lysimeters.

The usual practices of management of a banana tree (thinning, defoliation, propping, heart pruning, control of diseases, pests and invaders) were carried out according to need, according to Borges and Souza (2004). Fertigation was performed weekly, during which nitrogen (N) and potassium $(\mathrm{K})$ were applied in the form of potassium nitrate, obeying the following distribution: 
$10 \%$ in the first three months of planting, $75 \%$ from the third to the eighth month, in the bloom phase, and $15 \%$ from this until harvest, with applications in concentrations 3,6 and $9 \mathrm{~g} / \mathrm{L}$ (Borges and Souza, 2004).

Table 1. Chemical characterization of soils studied.

\begin{tabular}{lcc}
\hline Characteristics & Sandy-clay soil & Sandy soil \\
\hline $\mathrm{pH}$ & 5.0 & 7.6 \\
$\mathrm{P}\left(\mathrm{mg} \mathrm{d}^{-3}\right)$ & 2 & 28 \\
$\mathrm{~K}\left(\mathrm{cmolc} \mathrm{dm}^{-3}\right)$ & 0.06 & 0.06 \\
$\mathrm{Ca}\left(\mathrm{cmolc} \mathrm{dm}^{-3}\right)$ & 0.68 & 1.41 \\
$\mathrm{Mg}\left(\mathrm{cmolc} \mathrm{dm}^{-3}\right)$ & 0.46 & 0.30 \\
$\mathrm{Ca}+\mathrm{Mg}\left(\mathrm{cmolc} \mathrm{dm}^{-3}\right)$ & 1.14 & 1.71 \\
$\mathrm{Al}\left(\mathrm{cmolc} \mathrm{dm}^{-3}\right)$ & 0.5 & 0.0 \\
$\mathrm{Na}\left(\mathrm{cmolc} \mathrm{dm}^{-3}\right)$ & 0.33 & 0.02 \\
$\mathrm{H}+\mathrm{Al}\left(\mathrm{cmolc} \mathrm{dm}^{-3}\right)$ & 3.19 & 0.00 \\
$\mathrm{SB}$ & 1.53 & 1.84 \\
$\mathrm{CTC}$ & 4.72 & 1.84 \\
$\mathrm{~V}(\%)$ & 32.0 & 100 \\
$\mathrm{MO}\left(\mathrm{g} \mathrm{kg}^{-3}\right)$ & 12.0 & 9.0 \\
\hline
\end{tabular}

Table 2. Physical characteristic of the lysimeter soil.

\begin{tabular}{|c|c|c|c|c|c|c|c|c|}
\hline \multirow{2}{*}{ Characteristics } & \multicolumn{8}{|c|}{ Soil layers (m) } \\
\hline & $0.0-0.2$ & $0.2-0.4$ & $0.4-0.6$ & $0.6-0.8$ & $0.0-0.2$ & $0.2-0.4$ & $0.4-0.6$ & $0.6-0.8$ \\
\hline & \multicolumn{4}{|c|}{ Sandy soil } & \multicolumn{4}{|c|}{ Sandy-clay soil } \\
\hline Ps $(\%)$ & 36.47 & 31.49 & 35.49 & 35.97 & 43.93 & 44.49 & 48.33 & 45.56 \\
\hline $\mathrm{BD}\left(\mathrm{g} \mathrm{cm}^{-3}\right)$ & 1.62 & 1.76 & 1.71 & 1.66 & 1.41 & 1.46 & 1.34 & 1.40 \\
\hline Sand (\%) & 84.65 & 84.80 & 84.90 & 83.90 & 51.40 & 47.60 & 51.40 & 47.00 \\
\hline Silt (\%) & 8.75 & 8.65 & 8.50 & 9.55 & 10.10 & 9.90 & 7.10 & 8.50 \\
\hline Clay (\%) & 6.60 & 6.55 & 6.60 & 6.55 & 38.50 & 42.50 & 41.50 & 44.50 \\
\hline
\end{tabular}

Ps: porosity; BD: bulk density.

The development phases of the banana tree were: initial: 15/11/2014 to 04/01/2015 - 1 to 138 days after planting (DAP); vegetative growth: 02/04 to 07/20/2015 - 139 to 248 DAP; blooming: $21 / 07 / 2015$ to $09 / 07 / 2015$ - 249 to 297 DAP fruit growth: $07 / 09 / 2015$ to $12 / 02 / 2015$ - 298 to 383 DAP. The emission of the banana tree inflorescence planted on sandy clay soil occurred on 07/21/2015 and on sandy soil on 08/10/2015.

The irrigation management was carried out based on the data of water content measured using TDR probes, while calculating the volume of water necessary to return the water content values to the field capacity. The irrigation was performed with a fixed irrigation shift and an interval of two days, therefore making the irrigation water depth variable, and adopting as reference the data of water availability in the soil.

To determine the volumetric water content, from the apparent dielectric constant (Ka), the calibration of the TDR for the soils was previously performed according to (Equation 1) and (Equation 2).

$$
\begin{aligned}
& \theta_{\text {Areia franca }}=4.10^{-5} \varepsilon^{3}-0.0012 \varepsilon^{2}+0.0277 \varepsilon-0.1238 \\
& \theta_{\text {Argiloarenoso }}=6.10^{-5} \varepsilon^{3}-0.0032 \varepsilon^{2}+0.0631 \varepsilon-0.2422
\end{aligned}
$$


Where,

$\varepsilon$ - dielectric constant of the soil.

The precipitation was measured by means of a rain gauge installed in the area near the lysimeter, and was included in the irrigation calculation. The water depth drained in the lysimeters were measured at the outlets of the drainage systems. This way the water storage in the soil was calculated for the four radial planes $(0.20 \mathrm{~m} \times 0.20 \mathrm{~m})$, corresponding to the horizontal and vertical distances $(0.20 ; 0.40 ; 0.60$ and $0.80 \mathrm{~m})$ using (Equation 3$)$ :

$A(z)=\int_{0}^{L} \theta(z) d z$

Where:

$\theta(\mathrm{z})=$ is the representative function of the moisture profile $\left(\mathrm{L}^{3} \mathrm{~L}^{-3}\right)$;

$\mathrm{Z}=$ vertical coordinate $(\mathrm{L})$;

$\mathrm{L}=$ is the total depth $(\mathrm{L})$;

$\mathrm{A}(\mathrm{z})=$ water storage in the soil $(\mathrm{L})$.

The Simpson rule was used to solve the numerical integral.

The evapotranspiration of the crop was obtained by means of (Equation 4). The soil-water balance was carried out with the water depth infiltrated and extracted from the system in the times immediately before the day's irrigation, after irrigation and before the next irrigation.

$\Delta \mathrm{A}=\mathrm{I}+\mathrm{P}-\mathrm{D}-\mathrm{ET}$

In which:

$\Delta \mathrm{A}=$ storage variation $(\mathrm{L})$;

$\mathrm{I}=$ irrigation $(\mathrm{L})$;

$\mathrm{P}=$ precipitation $(\mathrm{L})$;

$\mathrm{D}=$ drainage $(\mathrm{L})$;

$\mathrm{ET}=$ Evapotranspiration $(\mathrm{L})$.

The mathematical models developed by Vogeler et al. (1996) and Muñoz-Carpena et al. (2005) related the electrical conductivity of the soil solution (CEw), apparent electrical conductivity (CEa) and soil moisture $(\theta)$, (Equation 5) and (Equation 6), respectively.

$$
\begin{aligned}
& \mathrm{CE}_{\mathrm{w}}=\frac{\mathrm{CEa}-(\mathrm{a} \theta+\mathrm{b})}{\mathrm{c} \theta-\mathrm{d}} \\
& \mathrm{CE}_{\mathrm{w}}=\frac{\mathrm{CEa}-\mathrm{c} \theta^{2}}{\mathrm{a} \theta^{2}-\mathrm{b} \theta}
\end{aligned}
$$

Where:

$\mathrm{a}, \mathrm{b}, \mathrm{c}$ and $\mathrm{d}$ - equation adjustment parameters. 
The CEa conductivity values were corrected for a temperature of $25^{\circ} \mathrm{C}$ by multiplying them by the correction factor $\left(\mathrm{f}_{\mathrm{T}}\right)$, which was calculated with (Equation 7) (Richards, 1954).

$$
\mathrm{f}_{\mathrm{T}}=1+\frac{(25-\mathrm{T})}{49.7}+\frac{(25-\mathrm{T})^{2}}{3728}
$$

Where:

$\mathrm{T}=$ Soil temperature, ${ }^{\circ} \mathrm{C}$.

After adjusting the parameters of the models that relate $\mathrm{CEw}, \mathrm{CEa}$ and $\theta$ it was possible to relate $\mathrm{CEw}$ to the specific concentration of a certain ion (Ci) present in the soil solution using (Equation 8) and (Equation 9) (Santana et al., 2007; Muñoz-Carpena et al., 2005):

Potential type $\mathrm{CEw}-\mathrm{Ci}$ relationship:

$C E_{w}=\alpha C i^{\mu}$

CEw-Ci ratio of linear type:

$C E_{w}=\alpha+\mu C i$

Where:

$\mathrm{Ci}$ - is the nitrate concentration $\left(\mathrm{mg} \mathrm{L}^{-1}\right)$

$\mathrm{CE}_{\mathrm{w}}$ - is the electrical conductivity of the soil solution $\left(\mathrm{dS} \mathrm{m}^{-1}\right)$ and

$\alpha$ e $\mu$ - are adjustment parameters of the equation.

The concentrations of nutrients were determined by means of (Equation 10), (Equation 11), (Equation 12) and (Equation 13).

Model de Vogeler et al. (1996) adapted for the potential-type CEw-Ci relationship:

$C i=\left\{\frac{1}{\mu} \frac{[C E a-(a \theta-b)]}{c \theta-d}\right\}^{\frac{1}{\mu}}$

Model of Vogeler et al., (1996) adapted for the linear-type CEw-Ci relationship:

$C i=\left\{\frac{[C E a-(a \theta-b)]}{c \theta-d}-\alpha\right\} \frac{1}{\mu}$

Model of Muñoz-Carpena et al. (2005) adapted for the potential-type CEw-Ci relationship:

$C i=\left\{\frac{1}{\mu}\left(\frac{C E a-c \theta^{2}}{a \theta^{2}-b \theta}\right)\right\}^{\frac{1}{\mu}}$

Model of Muñoz-Carpena et al. (2005) adapted for the linear-type CEw-Ci relationship:

$C i=\left\{\left(\frac{C E a-c \theta^{2}}{a \theta^{2}-b \theta}\right)-\alpha\right\} \frac{1}{\mu}$

The calibration of Equations 10, 11, 12 and 13 was performed through a lysimeter test, in which different values of electrical conductivity and water content of the soil were established. The values of electrical conductivity in the soil were obtained from the application of potassium 
nitrate solution in different concentrations $\left(3,6\right.$ and $\left.9 \mathrm{~g} \mathrm{~L}^{-1}\right)$ and the water content of the soil, which varied in values from borderline saturation to the minimum water content necessary for the extractor to remove the solution.

The soil solution was extracted by applying a suction of $70 \mathrm{kPa}$ four hours after the soil solution samples were collected.

While the extractor removed the solution to determine the electrical conductivity of the soil solution $(\mathrm{CEw})$, the $\mathrm{CEa}$ and $\theta$ readings were monitored every 10 minutes with the TDR, starting at the time of suction application and ending at the time of solution collection.

The electrical conductivity of the soil solution and the leached volume of the lysimeters were evaluated with the bench conductivimeter. The concentrations of nitrate and potassium present in these samples were monitored using the rapid determination kit (Card Horiba), according to Coelho et al. (2014).

The adjustment of the equations to the data and the evaluation of the models were based on the coefficient of determination $\left(\mathrm{R}^{2}\right)$ (Equation 14), Willmott's concordance index (d) (Equation 15) and the root-mean-square error (RMSE) (Equation 16).

$$
\begin{aligned}
& \mathrm{R}^{2}=1-\frac{\mathrm{SQR}}{\text { SQtot }} \\
& \mathrm{d}=1-\left[\sum_{\mathrm{i}=1}^{\mathrm{n}}\left(\mathrm{E}_{\mathrm{i}}-\mathrm{O}_{\mathrm{i}}\right)^{2} / \sum_{\mathrm{i}=1}^{\mathrm{n}}\left(\left|\mathrm{E}_{\mathrm{i}}-\overline{\mathrm{O}}\right|+\left|\mathrm{O}_{\mathrm{i}}+\overline{\mathrm{O}}\right|\right)^{2}\right] \\
& R M S E=\sqrt{\frac{1}{n} \sum_{i=1}^{n}\left(O_{i}-E_{i}\right)^{2}}
\end{aligned}
$$

Where:

$\mathrm{SQR}=$ residual sum of squares;

SQtot = sum of total square;

$\mathrm{n}=$ number of data;

$O_{i}=$ observed value;

$\bar{O}=$ average of estimated value;

$\mathrm{E}_{\mathrm{i}}=$ estimated value.

In addition to these statistical indicators, Pearson's correlation coefficient (r) (Figueiredo Filho and Silva Júnior, 2009) and the "c" index (according to the methodology presented by Ponciano, 2012) were also used to indicate the performance of the model.

The "c" index brings together the correlation coefficient $(r)$ and the agreement index $(d)$ (Equation 17), expressed as follows:

$$
\mathrm{c}=\mathrm{rxd}
$$

The criterion for interpreting the performance of the model according to index "c" (Equation 17) is: > 0.85 - Great; 0.76 to 0.85 - Very good; 0.66 to 0.75 - Good; 0.61 to 0.65 Average; 0.51 to 0.60 - Sufferable; 0.41 to 0.50 - Bad and $\leq 0.41$ - Very bad.

After adjusting the parameters of the models and identifying the one that best explains the relation between $\mathrm{CEw}, \mathrm{CEa}$ and $\theta$ in conjunction with the specific concentration of $\mathrm{NO}_{3}{ }^{-}$and $\mathrm{K}^{+}$present in the soil solution, the model selected in the lysimeter can be gradually validated during fertigation by collecting weekly extractions of the soil solution in the phases of 
vegetative growth, flowering and fruit growth of the banana tree.

For the evaluation of the simulated and observed values, the following statistical indexes were used: the concordance coefficient (d) (Equation 15), proposed by Willmontt (1981); the root-mean-square error (RMSE) (Equation 16); the degree of adjustment of the dependent variable $(\mathrm{Y})$ with the independent variable $(\mathrm{X})$, by establishing an equation of the type $\mathrm{Y}=\beta \mathrm{X}$ (" $\beta$ " is the angular coefficient); and the correlation coefficient of Pearson (r).

The modeling of water flow and solute transport was performed for all experimental plots with the Hydrus-2D software (Šimůnek et al., 2008), which simulated the three-dimensional axisymmetric and transient movement of water and nutrients in the soil. The transport domain was defined as a rectangle with a width of $100 \mathrm{~cm}$ (half the width of the lysimeter) and a depth of $100 \mathrm{~cm}$, as the sides of the flow domain the boundary conditions were defined as without water or nutrient flow. At the upper boundary of the flow domain the boundary condition was defined as an atmospheric boundary condition (variable flow condition of daily irrigation events, rainfall, and evapotranspiration), while at the lower boundary the condition was defined as free drainage, with 4 observation points at depths of 20,40, 60 and $80 \mathrm{~cm}$ inserted in the transport domain (Figure 1).

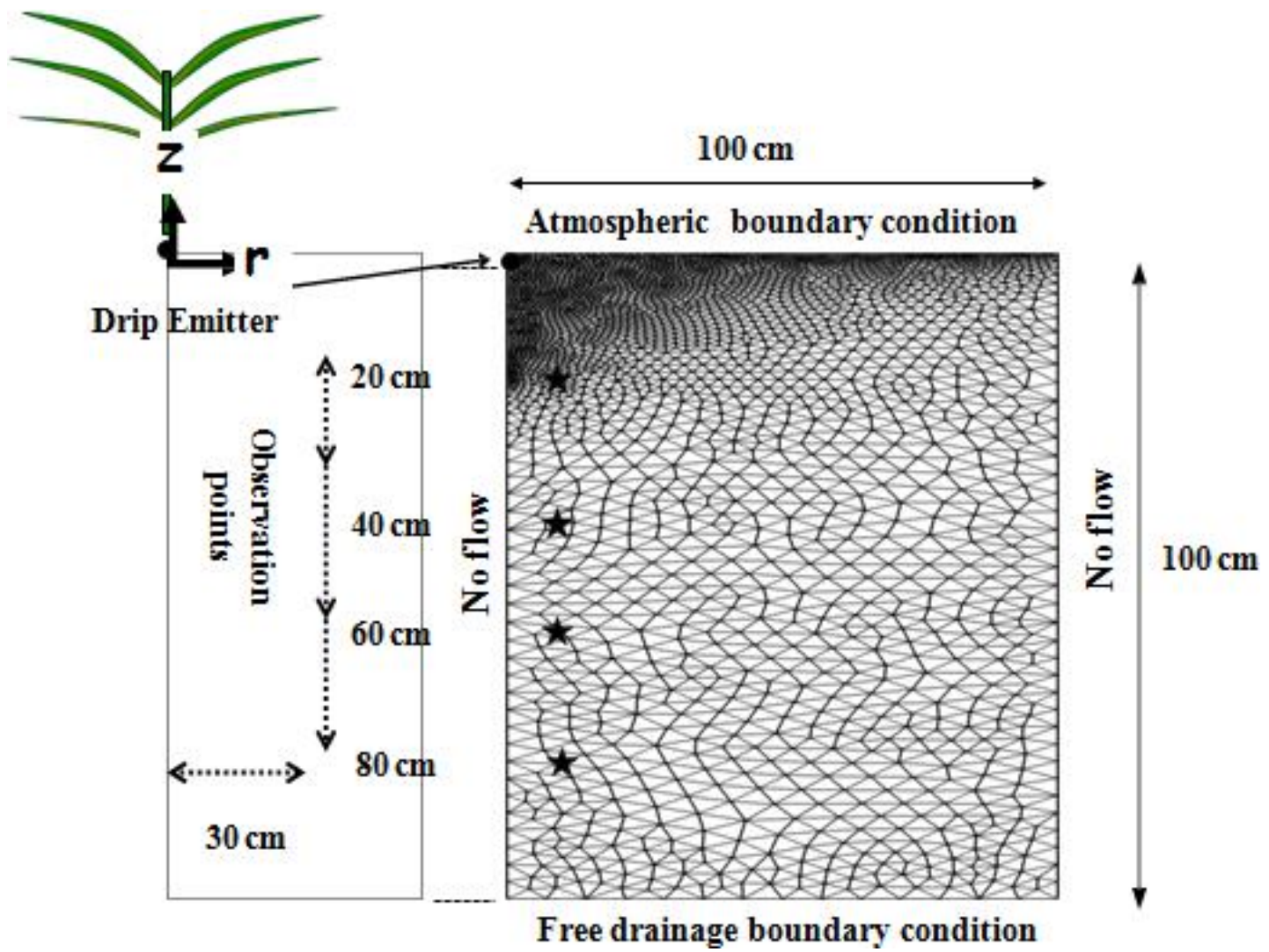

Figure 1. Location of the observation points in the soil profile and flow domain geometry with the boundary conditions used in the Hydrus-2D simulations.

The Hydrus-2D numerically solves the Richards equation describing water flow variability in a radially symmetrical domain as well as the convection-dispersion equation for the transport of solutes. The hydraulic properties of soil used to describe water flow were described using the van Genuchten-Mualem model (van Genuchten, 1980), (Table 3).

The distribution of solutes between the solid and liquid phases was described using a linear adsorption isothermal model. The parameters involved in the transport of the solute (coefficient of diffusion-dispersion $\mathrm{D}$, coefficient of retardation, $\mathrm{R}$ and velocity of water in the pore) were obtained by the method of miscible displacement (Table 4). 
Table 3. Parameters of the van Genuchten model for the two soils (Sandy-soil and Clay-sand) used in lysimeters.

\begin{tabular}{ccccccc}
\hline Soil & Soil layer & $\theta \mathrm{r}\left(\mathrm{cm}^{3} \mathrm{~cm}^{-3}\right)$ & $\theta \mathrm{s}\left(\mathrm{cm}^{3} \mathrm{~cm}^{-3}\right)$ & $\alpha\left(\mathrm{cm}^{-1}\right)$ & $\mathrm{N}$ & $\mathrm{Ks}\left(\mathrm{mm} \mathrm{day}^{-1}\right)$ \\
\hline \multirow{3}{*}{ Sandy Soil } & $0.00-0.20$ & 0.043 & 0.365 & 0.235 & 2.297 & 28.94 \\
& $0.20-0.40$ & 0.037 & 0.315 & 0.612 & 1.605 & 81.77 \\
& $0.40-0.60$ & 0.042 & 0.354 & 0.339 & 2.100 & 243.51 \\
& $0.60-0.80$ & 0.030 & 0.360 & 0.598 & 1.761 & 243.51 \\
\hline \multirow{3}{*}{ Clay sandy } & $0.00-0.20$ & 0.174 & 0.439 & 0.133 & 1.982 & 20.88 \\
& $0.20-0.40$ & 0.198 & 0.483 & 0.105 & 2.338 & 58.72 \\
& $0.40-0.60$ & 0.179 & 0.483 & 0.201 & 1.811 & 85.37 \\
& $0.60-0.80$ & 0.189 & 0.456 & 0.128 & 1.841 & 85.37 \\
\hline
\end{tabular}

Table 4. Parameters of nitrate and potassium transport: delay factor $(\mathrm{R})$, diffusive dispersive coefficient (D), number of Peclet (P), adsorption coefficient (KD) and (l).

\begin{tabular}{|c|c|c|c|c|c|c|c|c|c|c|}
\hline \multirow{3}{*}{ Conc. } & \multicolumn{9}{|c|}{ Nitrate } & \\
\hline & \multicolumn{4}{|c|}{ Sandy soil } & \multicolumn{6}{|c|}{ Sandy clay soil } \\
\hline & $\mathrm{R}$ & $\mathrm{KD}$ & $\mathrm{D}\left(\mathrm{cm}^{2} \mathrm{~h}^{-1}\right)$ & $\mathrm{P}(\mathrm{e})$ & $\lambda(\mathrm{cm})$ & $\mathrm{R}$ & $\mathrm{KD}$ & $\mathrm{D}\left(\mathrm{cm}^{2} \mathrm{~h}^{-1}\right)$ & $\mathrm{P}(\mathrm{e})$ & $\lambda(\mathrm{cm})$ \\
\hline 3 & 1.33 & 0.07 & 59.48 & 13.02 & 1.72 & 1.63 & 0.20 & 92.19 & 5.02 & 4.47 \\
\hline 6 & 1.40 & 0.08 & 73.70 & 10.93 & 2.05 & 1.68 & 0.22 & 76.18 & 6.34 & 3.54 \\
\hline \multirow[t]{2}{*}{9} & 1.68 & 0.14 & 43.80 & 17.36 & 1.29 & 1.71 & 0.23 & 64.23 & 7.16 & 3.13 \\
\hline & \multicolumn{9}{|c|}{ Potassium } & \\
\hline 3 & 1.71 & 0.14 & 27.12 & 28.56 & 0.79 & 1.96 & 0.31 & 73.14 & 6.33 & 3.55 \\
\hline 6 & 1.75 & 0.15 & 54.01 & 14.91 & 1.51 & 1.93 & 0.30 & 35.66 & 13.54 & 1.66 \\
\hline 9 & 1.92 & 0.18 & 56.44 & 13.47 & 1.67 & 2.11 & 0.36 & 46.07 & 9.99 & 2.25 \\
\hline
\end{tabular}

The methods of water absorption and root solute were determined by the model of Feddes et al. (1978) (Equation 18) for water absorption and for solute as a model without solute deficit:

$W U(h, r, z)=\gamma(h) * R D F(r, z) * W * T_{p o t}$

Where:

$\gamma(\mathrm{h})=$ water deficit function in the soil (adimensional);

$\mathrm{RDF}=$ normalized distribution of water absorption by the roots $(\mathrm{T})$;

Tpot $=$ potential perspiration rate $\left(\mathrm{L} \mathrm{T}_{-1}\right)$;

$\mathrm{W}=$ radius of soil surface associated with perspiration $(\mathrm{L})$.

$\mathrm{WU}=$ function of water absorption and solute by the roots $(\mathrm{T})$.

The parameters used by the model to simulate the potential of water extracted by the roots are presented in (Table 5). For such parameters, Hydrus assumes its nomenclature. The method of Feddes (1978) was applied. It relates the amount of water extracted from the soil as a function of root depth, with variables adopted by the software standard. Under optimal humidity conditions, the extraction of water by the root zone is equal to the potential perspiration rate.

For the items in the (Table 5), consider that $\mathrm{P} 2 \mathrm{H}=$ limit value for stress, below which roots cannot extract water at the maximum possible rate (assuming the potential rate of $\mathrm{r} 2 \mathrm{H}$ ); $\mathrm{P} 2 \mathrm{~L}=$ the same as above with potential perspiration rate of $r 2 \mathrm{~L} ; \mathrm{r} 2 \mathrm{H}=$ is the potential perspiration rate 
fixed at $0.5 \mathrm{~cm} \mathrm{day}^{-1}$ and $\mathrm{r} 2 \mathrm{~L}=$ potential perspiration rate fixed at $0.1 \mathrm{~cm}$ per day ${ }^{-1}$.

Table 5. Parameters used by the model to simulate the potential of water extracted by the root.

\begin{tabular}{cccccccc}
\hline Hydrus parameter & $\mathrm{P} 0(\mathrm{~cm})$ & $\mathrm{P} 0 \mathrm{pt}$ & $\mathrm{P} 2 \mathrm{H}$ & $\mathrm{P} 2 \mathrm{~L}$ & $\mathrm{P} 3$ & $\mathrm{r} 2 \mathrm{H}$ & $\mathrm{r} 2 \mathrm{~L}$ \\
\hline & \multicolumn{7}{c}{$\mathrm{cm}$} \\
\hline Adopted value & -10 & -25 & -300 & -1500 & -8000 & 0.5 & 0.1 \\
\hline
\end{tabular}

In the Hydrus model, a database for different plants regarding the parameters of water absorption by the roots is provided based on studies by Taylor and Ashcroft (1972).

In Hydrus, the model of solute absorption by the roots was also selected, for which it was assumed that the absorption of solutes was proportional to the product of the flow of water absorbed by the roots and the concentration of the solute dissolved in water.

The simulations along the lysimeter drainage profile were performed for the different phases of the crop for a total of 372 days, and compared the nitrate and potassium concentrations simulated by the Hydrus model during fertigation through the data observed from the extraction of the soil solution in the phases of vegetative growth, flowering and fruit growth of the banana tree.

The procedure for minimizing errors between measured and simulated data was outlined in the calibration using an iterative process in which the values of the model parameters were changed with each attempt. The scenarios considered the variations of: the water content obtained from the TDR sensors installed in the lysimeter; the hydraulic properties; time; the solute transport parameters and the initial concentrations of the solute. These were used as a basis for changes and adjustments in the model to make it safer to allow a better understanding of the water and nutrient dynamics involved, as well as the prediction of future scenarios. The observation period used for the calibration was the initial phase of the banana tree. During this phase, manual calibration was used to estimate the values of the parameters that best represented the observed values. Once the parameters of the model had been calibrated, it was validated for the other periods of banana cultivation.

After the simulations with the Hydrus-2D computer model, the following statistical indexes were used: Willmontt's (1981) concordance coefficient (d) (Equation 15); the rootmean-square error (RMSE) (Equation 16); the degree of adjustment of the dependent variable (Y) with the independent variable $(X)$, by establishing an equation of the type $Y=\beta X$ ( " $\beta$ " is the angular coefficient); and the correlation coefficient of Pearson (r) to compare the mean values of nitrate and potassium measured in the soil solution and simulated by the Hydrus-2D software.

\section{RESULTS AND DISCUSSION}

The models of Vogeler et al. (1996) and Muñoz-Carpena et al. (2005) presented low RMSE $(<0.1920)$ and agreement index (d) values close to the unit $(0.9999)$.

The model of Vogeler et al. (1996) showed a higher coefficient of regression determination for the soils under study, which led to a better classification (Very good: sandy soil and sandy clay) as to the ability to estimate $\mathrm{CEw}$ from $\mathrm{CEa}$ and $\theta$, when compared to the model of MuñozCarpena et al. (2005) (Good: sandy soil and sandy clay) (Table 6).

These results are corroborated by those of Ponciano (2012), who observed that in CEw's estimate the model of Vogeler et al. (1996) adjusts better to soils with clay texture characteristics both by the application of $\mathrm{KCl}$ and by the application of $\mathrm{KNO}_{3}$ via irrigation water, and in sandy soil the models from Vogeler et al. (1996) and Munõz-Carpena et al. (2005) presented a similar quality of adjustments being classified as "Very good". 
Table 6. Models for CEw estimation of sandy clay and sandy soils.
Soil
Model
$\mathrm{R}^{2}$
r
d RMSE Classif. of the Method $(c=r \times d)$

\begin{tabular}{|c|c|c|c|c|c|c|c|}
\hline \multirow{2}{*}{ Sandy Soil } & Vogeler et al., (1996) & $\mathrm{CE}_{\mathrm{w}}=\frac{\left[\mathrm{CE}_{\mathrm{a}}+2.5438 \theta-0.3730\right]}{-0.0871 \theta+0.7388}$ & 0.818 & 0.859 & 0.998 & 0.1677 & Very good \\
\hline & Muñoz-Carpena et al., (2005) & $C E_{w}=\frac{C E_{a}+19.6472 \theta^{2}}{-41.3941 \theta^{2}+19.4093 \theta}$ & 0.754 & 0.871 & 0.999 & 0.1537 & Good \\
\hline \multirow{2}{*}{ Sandy clay } & Vogeler et al., (1996) & $\mathrm{CE}_{\mathrm{w}}=\frac{\left[\mathrm{CE}_{\mathrm{a}}-0.0315 \theta-0.1111\right]}{-0.4152 \theta+0.4264}$ & 0.779 & 0.883 & 0.999 & 0.1538 & Very good \\
\hline & Muñoz-Carpena et al., (2005) & $\mathrm{CE}_{\mathrm{w}}=\frac{\mathrm{CE}_{\mathrm{a}}-1.0981 \theta^{2}}{-10.0371 \theta^{2}+4.3187 \theta}$ & 0.655 & 0.830 & 0.999 & 0.1920 & Good \\
\hline
\end{tabular}

For both soils, there was a positive correlation $(\mathrm{r}+$ ) for the estimation of nitrate and potassium concentration in the soil solution from water content data $(\theta)$ and apparent electrical conductivity $(\mathrm{CEa})$ when a linear or power type relation is introduced to the adapted models (Vogeler $e t$ al., 1996; Munõz-Carpena et al., 2005). This can be seen in the slight differences between the determination coefficients, thus presenting the same classification for the "c" index for the $\mathrm{CEw}-\mathrm{NO}_{3}{ }^{-}$ratio of the linear type and power type (Table 7), which was also observed in the $\mathrm{CEw}-\mathrm{K}^{+}$ratio of the linear type and power type (Table 8).

In general, despite the concordance index (d) close to the unit (0.9999), the model of Vogeler et al. (1996) was superior to the model of Muñoz-Carpena et al. (2005), and always presented lower RMSE and higher coefficient of determination $\left(\mathrm{R}^{2}\right)$. This led the model of Vogeler $e t$ al. (1996) to present a better classification according to the "c" index for the models estimating nitrate and potassium concentration (mg $\mathrm{L}^{-1}$ ) for sandy soil and sandy clay (Table 7 and 8 ).

The results of this study agree with those obtained by Santana et al. (2006), who reported that, regarding the models used, Rhoades et al., (1976) and Vogeler et al. (1996) provided the best estimates of K concentration in soil solution. For both soils, the model of Vogeler et al. (1996) adapted to the linear type $\mathrm{CEw}-\mathrm{Ci}$ ratio (Equation 9) was chosen to estimate the concentration of nitrate and potassium in the soil solution after the first cycle of banana crop in the drainage lysimeter. 
Table 7. Models for estimation of nitrate concentration $\left(\mathrm{mg} \mathrm{L}^{-1}\right)$ for sandy soil and sandy clay.
Soil
Model
$\mathrm{R}^{2} \quad \mathrm{r}$
d RMSE Classif. of the Method $(c=r x d)$

Adapted for linear type $\mathrm{CEw}-\mathrm{NO}_{3}{ }^{-}$ratio

\begin{tabular}{|c|c|c|c|c|c|c|c|}
\hline Sandy soil & Vogeler et al., (1996) & $\begin{array}{l}\mathrm{NO}_{3}{ }^{-} \\
=[\mathrm{CEw}-0.0283] \frac{1}{0.0024}\end{array}$ & 0.7581 & 0.867 & 0.9999 & 66.7749 & Very good \\
\hline Sandy soil & Muñoz-Carpena et al., (2005) & $\begin{array}{l}\mathrm{NO}_{3}{ }^{-} \\
=[\mathrm{CEw}-0.0860] \frac{1}{0.0024}\end{array}$ & 0.6158 & 0.785 & 0.9999 & 90.0959 & Average \\
\hline $\begin{array}{l}\text { Sandy } \\
\text { clay }\end{array}$ & Vogeler et al., (1996) & $\begin{array}{l}\mathrm{NO}_{3}{ }^{-} \\
=[\mathrm{CEw}-0.0955] \frac{1}{0.0034}\end{array}$ & 0.8568 & 0.926 & 0.9999 & 35.1413 & Great \\
\hline $\begin{array}{l}\text { Sandy } \\
\text { clay }\end{array}$ & Muñoz-Carpena et al., (2005) & $\begin{array}{l}\mathrm{NO}_{3}{ }^{-} \\
=[\mathrm{CEw}-0.2126] \frac{1}{0.0027}\end{array}$ & 0.8352 & 0.917 & 0.9995 & 37.6901 & Very good \\
\hline
\end{tabular}

Adapted for power type $\mathrm{CEw}-\mathrm{NO}_{3}{ }^{-}$ratio

\begin{tabular}{lccccccc}
\hline Sandy soil & Vogeler et al., (1996) & $\mathrm{NO}_{3}{ }^{-}=\left[\frac{1}{0.0038} \mathrm{CEw}\right]^{\frac{1}{0.9257}}$ & 0.7596 & 0.868 & 0.9999 & 69.1431 & Very good \\
Sandy soil & $\begin{array}{c}\text { Muñoz-Carpena } \text { et al. }, \\
(2005)\end{array}$ & $\mathrm{NO}_{3}{ }^{-}=\left[\frac{1}{0.0074} \mathrm{CEw}\right]^{\frac{1}{0.8242}}$ & 0.6212 & 0.786 & 0.9998 & 90.0767 & Average \\
$\begin{array}{c}\text { Sandy } \\
\text { clay }\end{array}$ & Vogeler et al., (1996) & $\mathrm{NO}_{3}{ }^{-}=\left[\frac{1}{0.0108} \mathrm{CEw}\right]^{\frac{1}{0.7994}}$ & 0.8658 & 0.940 & 0.9998 & 32.5036 & Great \\
$\begin{array}{c}\text { Sandy } \\
\text { clay }\end{array}$ & $\begin{array}{c}\text { Muñoz-Carpena } \text { et al. } . \\
(2005)\end{array}$ & $\mathrm{NO}_{3}{ }^{-}=\left[\frac{1}{0.0231} \mathrm{CEw}\right]^{\frac{1}{0.6623}}$ & 0.8202 & 0.909 & 0.9998 & 39.3716 & Very good \\
\hline
\end{tabular}


Table 8. Models for potassium concentration estimation $\left(\mathrm{mg} \mathrm{L}^{-1}\right)$ for sandy soil and sandy clay.

\begin{tabular}{|c|c|c|c|c|c|c|c|}
\hline Soil & \multicolumn{2}{|c|}{ Model } & $\mathrm{R}^{2}$ & $\mathrm{r}$ & $d$ & RMSE & $\begin{array}{l}\text { Classif. of the Method } \\
\qquad(\mathrm{c}=\mathrm{r} \times \mathrm{d})\end{array}$ \\
\hline & & & \multicolumn{5}{|c|}{ Adapted for linear type $\mathrm{CEw}-\mathrm{K}^{+}$ratio } \\
\hline Sandy soil & Vogeler et al., (1996) & $\mathrm{K}^{+}=[\mathrm{CEw}-0.0274] \frac{1}{0.0076}$ & 0.7134 & 0.840 & 0.9999 & 23.6440 & Good \\
\hline Sandy soil & Muñoz-Carpena et al., (2005) & $\mathrm{K}^{+}=[\mathrm{CEw}-0.0731] \frac{1}{0.0077}$ & 0.5580 & 0.747 & 0.9999 & 29.0023 & Sufferable \\
\hline Sandy clay & Vogeler et al., (1996) & $\mathrm{K}^{+}=[\mathrm{CEw}+0.0191] \frac{1}{0.0059}$ & 0.6563 & 0.822 & 0.9994 & 41.4654 & Good \\
\hline Sandy clay & Muñoz-Carpena et al., (2005) & $\mathrm{K}^{+}=[\mathrm{CEw}-0.1637] \frac{1}{0.0039}$ & 0.6222 & 0.789 & 0.9999 & 43.4716 & Average \\
\hline
\end{tabular}

Adapted for power type $\mathrm{CEw}-\mathrm{K}^{+}$ratio

\begin{tabular}{lccllllll}
\hline Sandy soil & Vogeler et al., (1996) & $\mathrm{K}^{+}=\left[\frac{1}{0.0121} \mathrm{CEw}\right]^{\frac{1}{0.9073}}$ & 0.7165 & 0.843 & 0.9999 & 23.5022 & Good \\
Sandy soil & Muñoz-Carpena et al., (2005) & $\mathrm{K}^{+}=\left[\frac{1}{0.0167} \mathrm{CEw}\right]^{\frac{1}{0.8529}}$ & 0.5614 & 0.749 & 0.9998 & 28.8929 & Sufferable \\
Sandy clay & Vogeler et al., (1996) & $\mathrm{K}^{+}=\left[\frac{1}{0.0094} \mathrm{CEw}\right]^{\frac{1}{0.9041}}$ & 0.6430 & 0.827 & 0.9964 & 41.5647 & Average \\
Sandy clay & Muñoz-Carpena et al., (2005) & $\mathrm{K}^{+}=\left[\frac{1}{0.0173} \mathrm{CEw}\right]^{\frac{1}{0.7562}}$ & 0.6098 & 0.782 & 0.9998 & 44.1795 & Average \\
\hline
\end{tabular}


During the validation of the model in the drainage lysimeter, there was an underestimation of the nitrate and potassium values predicted as a function of the ion measured in the soil solution (Table 9). In sandy soil, mean nitrate values were underestimated by $2 \%, 13 \%$, and $11 \%$, and mean potassium values by $4 \%, 12 \%$, and $9 \%$ for concentrations of 3,6 , and $9 \mathrm{~g} \mathrm{~L}^{-1}$, respectively. In the sandy clay soil, there was also an underestimation of the mean values of nitrate $\left(13 \%, 6 \%\right.$ and $4 \%$ for 3,6 and $\left.9 \mathrm{~g} \mathrm{~L}^{-1}\right)$ and potassium $(8 \%, 6 \%$ and $9 \%$ for 3,6 and $9 \mathrm{~g}$ $\left.\mathrm{L}^{-1}\right)$ (Table 9).

Table 9. Statistical indications for comparison of mean values of nitrate and potassium measured in the soil solution and estimated by the Vogeler et al. (1996) model adapted to the linear type CEw-Ci ratio.

\begin{tabular}{ccccccccccc}
\hline \multirow{2}{*}{ Soil } & \multirow{3}{*}{ Concentration $\mathrm{g} \mathrm{L}^{-1}$} & \multicolumn{4}{c}{ Nitrate } & \multicolumn{7}{c}{ Potassium } \\
\cline { 3 - 10 } & & $\beta$ & $\mathrm{R}^{2}$ & $\mathrm{~d}$ & $\mathrm{RMSE}$ & $\beta$ & $\mathrm{R}^{2}$ & $\mathrm{~d}$ & $\mathrm{RMSE}$ \\
\hline \multirow{3}{*}{ sand and soil } & 3.0 & 0.98 & 0.72 & 0.99 & 27.20 & 0.96 & 0.69 & 0.99 & 6.638 \\
& 6.0 & 0.87 & 0.67 & 0.99 & 32.17 & 0.88 & 0.72 & 0.99 & 7.89 \\
& 9.0 & 0.89 & 0.70 & 0.99 & 18.63 & 0.91 & 0.74 & 0.99 & 9.201 \\
\hline \multirow{3}{*}{ sand and clay } & 3.0 & 0.87 & 0.85 & 0.99 & 31.98 & 0.92 & 0.67 & 0.99 & 10.20 \\
& 6.0 & 0.94 & 0.72 & 0.99 & 23.54 & 0.84 & 0.71 & 0.99 & 16.24 \\
& 9.0 & 0.96 & 0.69 & 0.99 & 22.78 & 0.91 & 0.74 & 0.99 & 15.01 \\
\hline
\end{tabular}

Andrade Neto et al. (2012), while using a potential model combined with the model of Vogeler et al. (1996), reported a general variation of $20.0 \%$ (average of normalized errors) for the measured values compared to those estimated in Yellow Latosol with sandy soil texture. According to Andrade Neto and Coelho (2014), these variations in the values may be acceptable in soil ion management due to the spatial variability of soil chemical attributes. Thus, the results shown in (Table 9) validate the model used to estimate the nitrate and potassium ion in soil solution.

These results corroborate those of Andrade Neto et al. (2012), who concluded that it is feasible to estimate the concentration of $\mathrm{K}^{+}$in the soil solution from water content data and $\mathrm{CEa}$, obtained using the time domain reflectometry (TDR) technique for field conditions, while using an equation from the combination of a linear model and a potential. Santos et al. (2009) concluded that the TDR technique, together with the use of adjusted models, proved to be able to monitor the transport of solutes in the soil, regardless of the type of soil in use and the nutrient dosage applied.

The transport analysis of solutes contemplated the two-dimensional model. To evaluate the performance of the Hydrus-2D model, a joint analysis with statistical index "d" was performed to verify if there was an agreement between the simulated and experimental values. The value $\mathrm{d}=0$ shows that there is no agreement and the value $\mathrm{d}=1$ shows that there is total agreement.

It has been noted that in general the simulations performed for the displacement of nitrate and potassium in the soil showed high rates of agreement (d) and the values of RMSE were lower (Table 10) than those observed using the parametric model (Table 9), indicating that the values simulated by the Hydrus-2D software showed less dispersion of data.

The " $\beta$ " indexes confirm the performance of Hydrus-2D software in simulating the concentration of nitrate and potassium ion in the soil solution throughout the crop cycle. All the values of " $\beta$ " were close to the unit, presenting little difference with an overestimation of $6 \%$ of the nitrate values in the concentration of $3 \mathrm{~g} \mathrm{~L}^{-1}$ (sandy soil) and $7 \%$ and $2 \%$ of the nitrate values in the concentration of $3 \mathrm{~g} \mathrm{~L}^{-1}$ and $9 \mathrm{~g} \mathrm{~L}^{-1}$, respectively (sandy clay soil), while the other simulations in the Hydrus-2D software underestimated the nitrate and potassium values. 
Table 10. Statistical indicators for comparison of mean nitrate and potassium values measured in the soil solution and simulated by Hydrus-2D software.

\begin{tabular}{cccccccccc}
\hline \multirow{2}{*}{ Soil } & \multicolumn{4}{c}{ Nitrate } & \multicolumn{4}{c}{ Potassium } \\
\cline { 3 - 10 } & & \multicolumn{1}{c}{ Concentration $\mathrm{gL}^{-1}$} & $\mathrm{R}^{2}$ & $\mathrm{~d}$ & $\mathrm{RMSE}$ & $\beta$ & $\mathrm{R}^{2}$ & $\mathrm{~d}$ & RMSE \\
\hline \multirow{3}{*}{ Sandy soil } & 3.0 & 1.06 & 0.65 & 0.99 & 18.36 & 0.96 & 0.64 & 0.99 & 6.99 \\
& 6.0 & 0.97 & 0.57 & 0.99 & 14.83 & 0.92 & 0.75 & 0.99 & 8.85 \\
& 9.0 & 0.85 & 0.68 & 0.99 & 22.81 & 0.95 & 0.56 & 0.99 & 8.01 \\
\hline \multirow{3}{*}{ Sandy clay } & 3.0 & 1.07 & 0.70 & 0.99 & 19.06 & 0.86 & 0.68 & 0.99 & 9.66 \\
& 6.0 & 0.93 & 0.72 & 0.99 & 16.07 & 0.94 & 0.70 & 0.99 & 7.17 \\
& 9.0 & 1.02 & 0.64 & 0.99 & 17.38 & 0.97 & 0.71 & 0.99 & 6.78 \\
\hline
\end{tabular}

Montenegro et al. (2010), Silva et al. (2013), Montenegro et al. (2013), and Pinho and Miranda (2014) also used statistical indices to assess the quality of the fit between measured and simulated values.

The correlations between the average values of nitrate and potassium measured in the soil solution with the values simulated by the Hydrus-2D software and the values estimated by the Vogeler et al. (1996) model adapted to the linear type CEw-Ci ratio in loam sand and sandy clay soils, may be observed in Figure 2.
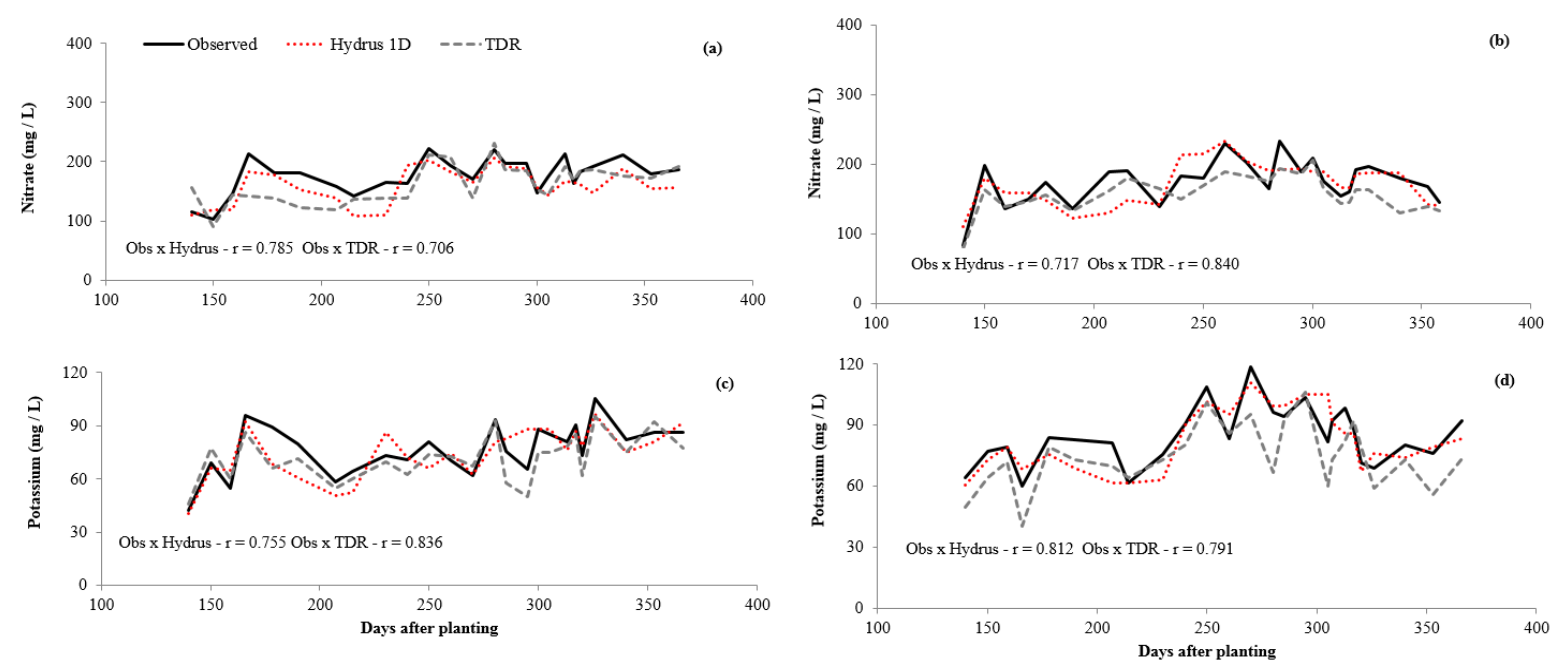

Figure 2. Average values of nitrate and potassium for concentrations 3,6 and $9 \mathrm{~g} \mathrm{~L}^{-1}$, measured in the soil solution with the values simulated by the Hydrus-2D software and the values determined by means of the TDR through the Vogeler et al. (1996) model adapted to the CEw-Ci ratio of the linear type in the sandy soil (a and c) and sandy clay (b and d).

It appears that the measured data differed little from the simulated data, in which both the Vogeler et al. (1996) adapted to the linear type CEw-Ci relationship and Hydrus-2D showed positive correlation $(\mathrm{r}+)$ with the measured data, which demonstrates the adequacy of these models for modeling the levels of nitrate and potassium in the soil solution. These results are in agreement with those obtained by Oliveira et al. (2010), Ribeiro et al. (2011) and Pinho and Miranda (2014) who stated that the Hydrus model was efficient in simulating the displacement of potassium and water.

In this study, all $\mathrm{r}$ values were above 0.70 , which shows a high correlation between measured and estimated data (Figure 2), according to the Cohen (1988) classification. Thus, it notes that the mathematical model used and the Hydrus-2D software have been proven as feasible tools that can be used satisfactorily to describe the nitrate and potassium concentration of the soil solution under field conditions. However, the possibility of variations in the 
parameter values required by the model needs precise adjustments to reflect the quality of the simulations, as the amount of input data required increases with the complexity of the simulations, due to the need for larger amounts of input parameters.

\section{CONCLUSIONS}

The mathematical models proved effective in estimating the concentration of nitrate and potassium in the soil solution during the banana crop cycle under field conditions, with greater accuracy and less dispersion for Vogeler et al. (1996) combined with the linear model.

The Hydrus-2D computer program proved to be feasible as a good tool for describing the nitrate and potassium concentration of the soil solution under the conditions under which the work was performed.

The concentrations of nitrate and potassium in the soil estimated by adapting the Vogeler et al. (1996) model to the linear type $\mathrm{CEw}-\mathrm{Ci}$ ratio, and simulated by the Hydrus model, presented an acceptable characterization of the distribution of these nutrients and their oscillations in the soil solution during the banana crop cycle, demonstrating satisfactory performance and feasibility of both methods.

\section{REFERENCES}

ANDRADE NETO, T. M.; COELHO, E. F. Concentração de potássio em função da condutividade elétrica da solução do solo. Water Resources and Irrigation Management , v. 3, p. 13-19, 2014. http://dx.doi.org/10.1590/S141543662012000600005

ANDRADE NETO, T. M. de; COELHO, E. F.; SANTANA, J. A. do V.; SANTANA JÚNIOR, E. B.; ALVES, M. da S. Estimativa de potássio na solução do solo baseada na condutividade elétrica e umidade do solo. Revista Brasileira de Engenharia Agrícola e Ambiental, v. 16, n. 6, p. 618-623, 2012.

BORGES, A. L.; SOUZA, L. da F. O Cultivo da bananeira. Cruz das Almas: Embrapa Mandioca e Fruticultura, 2004. 279 p.

COHEN, J. Statistical Power analysis for the behavioral sciences. Hillsdale: Erlbaum, 1988.

COELHO, E. F.; COSTA, F. da S.; SILVA, A. C. P. da; CARVALHO, G. C. Concentração de nitrato no perfil do solo fertigado com diferentes concentrações de fontes nitrogenadas. Revista Brasileira de Engenharia Agrícola e Ambiental, v. 18, n. 3, p. 263-269, 2014. http://dx.doi.org/10.1590/S1415-43662014000300004

ELMI, A.; NOHRA, J. S. A.; MADRAMOOTOO, C. A.; HENDERSHOT, W. Estimating phosphorus leachability in reconstructed soil columns using Hydrus-1D model.

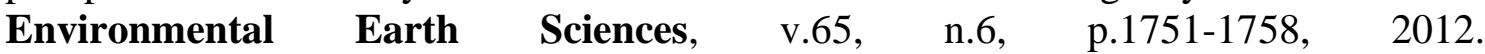
https://doi.org/10.1007/s12665-011-1154-1

FEDDES, R. A.; KOVALIK, P. J.; ZARADNY, H. Simulation of field water use and crop yield. New York: John Wiley,1978.188 p.

FIGUEIREDO FILHO, D.; SILVA JÚNIOR, J. A. da. Desvendando os Mistérios do Coeficiente de Correlação de Pearson (r). Revista Política Hoje, v. 18, n. 1, 2009.

GARCIA, W. V.; AlCÂNTARA, M. A. K.; CAMARGO, O. A.; IZÁRIO FILHO, H. J.; ANDREOTE, F. D. Deslocamento miscível de um efluente de indústria de explosivo em colunas de solo. Bragantia, v. 71, n. 1, p. 98-105, 2012. https://doi.org/10.1590/S000687052012000100015 
KANZARI, S.; HACHICHA, M.; BOUHLILA, R.; BATTLE-SALES, J. Characterization and modeling of water movement and salts transfer in a semi-arid region of Tunísia (BouHajla, Kairouan) - Salinization risk of soils and aquifers. Computers and $\begin{array}{llllll}\text { Electronics in } & \text { Agriculture, v. 86, p. 34-42, }\end{array}$ https://doi.org/10.1016/j.compag.2011.09.010

KISSEL, E.; VAN ASTEN, P.; SWENNEN, R.; LORENZEN, J.; CARPENTIER, S.C. Transpiration efficiency versus growth: Exploring the banana biodiversity for drought $\begin{array}{llllll}\text { tolerance. Scientia Horticulturae, v. } 2015 . & \text { 185, p.175-182, }\end{array}$ https://doi.org/10.1016/j.scienta.2015.01.035

KUNZ, J.; ÁVILA, V. S. de; PETRY, M. Distribuição temporal e espacial da umidade do solo em sistemas de irrigação por gotejamento subsuperficial. Revista Monografias Ambientais - REMOA, v. 13, n. 5, p. 3963-3976, 2014. https://doi.org/10.5902/2236130815123

LANGONI, J. A.; ASSIS, G. A.; SANTOS, L. C.; REZENDE, M. A. A.; VALOTO, B.; LEÃO, T. V. M. Produtividade de cafeeiros fertirrigados sob diferentes níveis de adubação na região do cerrado mineiro na primeira safra. Revista de Ciências Agroambientais, v. 17, p. 1-7, 2019. https://doi.org/10.5327/rcaa.v17i1.2128

MARTINEZ, M. A.; SILVA, J. B. G.; PEREIRA, D. R. Modelagem do movimento de sais no solo. In: RAJGHEYI, H.; DIAS, N. da S.; LACERDA, C. F. de. (Org.). Manejo da salinidade na agricultura: estudos básicos e aplicados. 1. ed. Fortaleza: INCTsal, 2010. v. 1, p. 93-113.

MONTENEGRO, S. G. L.; DA SILVA JUNIOR, J. G. ;MONTENEGRO, A. A. de A.; de CARVALHO, J. F.; ALBUQUERQUE FILHO, J. A. C. Experimentação e modelagem do avanço de sais no perfil do solo em área cultivada com repolho sob alternativas de manejo de irrigação, no semiárido de Pernambuco. Agrária - Revista Brasileira de Ciências Agrárias, v. 8, n. 1, 2013. https://dx.doi.org/10.5039/agraria.v8i1a1391

MONTENEGRO, S. G.; MONTENEGRO, A. A. de A.; RAGAB, R. Improving agricultural water management in the semiarid region of Brazil: experimental and modelling study. Irrigation Science, v. 28, n. 4, p. 301-316, 2010. https://doi.org/10.1007/s00271-0090191-y

MUÑOZ-CARPENA, R.; REGALADO, C. M.; RITTER, A.; ALVAREZ-BENEDÍ, J.; SOCORRO, A. R. TDR estimation of electrical conductivity and saline solute concentration in a volcanic soil. Geoderma, v. 124, p. 399-413, 2005. https://doi.org/10.1016/j.geoderma.2004.06.002

MUTHUSAMY, M.; UMA, S.; BACKIYARANI, S.; SARASWATHI, M. S. Computational prediction, identification, and expression profiling of microRNAs in banana (Musa spp.) during soil moisture deficit stress. The Journal of Horticultural Sciences \& $\begin{array}{llllllll}\text { Biotechnology, } & \text { v. } & 89, \quad \text { n. } & 2, & \text { p. } & 208- & 214,\end{array}$ https://doi.org/10.1080/14620316.2014.11513070

NIMMER, M.; THOMPSON, A; MISRA, D. Water table Mounding Beneath stormwater infiltration Basins. Environmental \& Engineering Geoscience, v. 19, n. 2, p. 67-79, 2009. https://doi.org/10.2113/gseegeosci.15.2.67

OLIVEIRA, N. T.; CASTRO, N. M. R.; GOLDENFUM, J. A. Influência da palha no balanço hídrico em lisímetros. Revista Brasileira de Recursos Hídricos, v. 15, p. 93-103, 2010. 
PERSSON, M.; UVO. C. B. Estimating soil solution electrical conductivity from time domain reflectometry measurements using neural networks. Journal of Hydrology, v. 273, n. 14, p. 249-256, 2003. https://doi.org/10.1016/S0022-1694(02)00387-6

PINHO, R. E. da C. de; MIRANDA, J. H. de. Avaliação do modelo Hydrus-1D na simulação do transporte de água e potássio em colunas preenchidas com solos tropicais. Engenharia Agrícola, v. 34, n. 5, p. 899-911, 2014. https://doi.org/10.1590/S010069162014000500009

PONCIANO, I. de M. Aplicação da reflectometria no domínio do tempo (TDR) na estimativa da condutividade elétrica da solução do solo e de concentrações de nitrato, potássio e cloreto em coluna de solo não saturado. 2012. Tese (Doutorado) Escola Superior de Agricultura "Luiz de Queiroz”, Piracicaba, 2012.

RAMOS. B. Z.; PAIS. P. S. M.; FREITAS. W. A.; D. JUNIOR. M. S. D. Avaliação dos atributos físico-hídricos em um Latossolo Vermelho distroférricosob diferentes sistemas de manejo-Lavras/Minas Gerais/Brasil. Revista de Ciências Agrárias, v. 36, n. 3, 2013.

RAVI, I.; UMA, S.; VAGANAM, M.M.; MUSTAFFA, M. M. Phenotyping bananas for drought resistance. Frontiers in physiology, v. 4, n. 1, p. 1-15, 2013. https://doi.org/10.3389/fphys.2013.00009

RHOADES, J. D.; RAATS, P. A.; PRATHER, R. J. Effects of liquid phase electrical conductivity, water content and surface conductivity on bulk soil electrical conductivity. Soil Science Society of America Journal, v. 40, n. 5, p. 651-655, 1976.

RIBEIRO, D. P.; MARTINEZ, M. A.; MATOS, A. T.; RUIZ, H. A.; PARREIRAS, M. S. N.; CECON, P. R. Relação da velocidade de escoamento da solução e do comprimento da coluna de solo com os parâmetros de transporte de potássio em um Latossolo e um Neossolo. Revista Brasileira de Ciência do Solo, v. 35, n. 6, p. 1907-1916, 2011. http://dx.doi.org/10.1590/S0100-06832011000600007

RICHARDS, L. A. Diagnosis and improvement of saline and alkali soils. Riverside: LWW, 1954.

RIVERA, R. N. C.; MIRANDA, J. H.; DUARTE, S. N.; BOTREL, T. A. Modelo aplicado à dinâmica da água e do potássio no solo sob irrigação por gotejamento - análise de sensibilidade. Revista de Engenharia Agrícola, v. 28, n. 3, p.448-459, 2008. http://dx.doi.org/10.1590/S0100-69162008000300006

SANTANA, G. S.; COELHO, E. F.; SILVA, T. S. M.; RAMOS, M. M. Relação entre potássio na solução do solo, umidade e condutividade elétrica aparente do solo. Revista Brasileira de Engenharia Agrícola e Ambiental, v. 11, n. 2, p. 142-157, 2007. http://dx.doi.org/10.1590/S1415-43662007000200003

SANTOS, M. R. dos; MARTINEZ, M. A.; ZONTA, J. H.; MATOS, A. T. de; OLIVEIRA, R. A. de. Uso da Reflectometria no Domínio do Tempo para avaliar a distribuição de nitrato em colunas de solos fertirrigados. Revista Ambiente \& Água, v. 4, n. 3, p. 67-81, 2009. https://dx.doi.org/10.4136/ambi-agua.103

SANTOS, M. R.; MARTINEZ, M. A.; ZONTA, J. H. Modelos para determinação de fósforo e nitrato em neossolo quartzarênico e latossolo vermelho usando TDR. Engenharia na Agricultura, v. 18, p. 30-39, 2010. https://doi.org/10.13083/reveng.v18i1.162 
SILVA, J. R. L.; MONTENEGRO, A. A. A.; MONTEIRO, A. L. N.; SILVA JUNIOR, V. P. Modelagem da dinâmica de umidade do solo em diferentes condições de cobertura no semiárido pernambucano. Agrária, v. 10, p. 293-303, 2015. https://dx.doi.org/10.5039/agraria.v10i2a4219

SILVA, L. L.; RAGAB, R.; DUARTE, I.; LOURENÇO, E.; SIMÕES, N.; CHAVES, M. M. Calibration and validation of SALTMED model under dry and wet year conditions using chickpea field data from Southern Portugal. Irrigation Science, v. 31, p. 651-659, 2013. https://doi.org/10.1007/s00271-012-0341-5

ŠIMU゚NEK, J.; VAN GENUCHTEN, M.Th.; ŠEJNA, M. Development and Applications of the Hydrus and STANMOD Software Packages and Related Codes. Vadose Zone Journal, v. 7, p. 587-600, 2008. https://doi.org/10.2136/vzj2007.0077

TAYLOR, S. A.; ASHCROFT, G. M. Physical edaphology. San Francisco: Freeman, 1972. $533 \mathrm{p}$.

VAN GENUCHTEN, M. Th. A closed-form equation for predicting the hydraulic conductivity of unsaturated soils. Soil science society of America journal, v. 44, n. 5, p. 892-898, 1980. https://doi.org/10.2136/sssaj1980.03615995004400050002x

VANHOVE, A. C.; VERMAELEN, W.; PANIS, B.; SWENNEN, R.; CARPENTIER, S. C. Screening the banana biodiversity for drought tolerance: can an in vitro growth model and proteomics be used as a tool to discover tolerant varieties and understand homeostasis. Frontiers in Plant Science, v. 3, n. 176, p. 1-10, 2012. https://doi.org/10.3389/fpls.2012.00176

VOGELER, I.; CLOTIER, B. E.; GREEN, S. R.; SCOTTER, D. R.; TILLMAN, R. W. Characterizing water and solute movement by TDR and disk permeametry. Soil Science Society of America Journal, v. 60, n. 1, p. 5-12, 1996. https://doi.org/10.2136/sssaj1996.03615995006000010004x

WILLMOTT, C. J. On the validation of models. Physical Geography, v. 2, n. 2, p. 184-194, 1981. https://doi.org/10.1080/02723646.1981.10642213 